\title{
In vitro screening of antifungal activity of marine sponge extracts against five phytopathogenic fungi
}

\author{
Belkassem El Amraoui ${ }^{1,2^{*}}$, Majida El Wahidi ${ }^{1}$ and Aziz Fassouane ${ }^{1}$
}

\begin{abstract}
The aim of our research is the screening of extracts of marine sponges for their antifungal activity against phytopathogenic fungi. The in vitro screening of hydroalcoholic and organic extracts of ten marine sponges from Atlantic coast of Morocco against five phytopathogenic fungi (Fusarium oxysporum f.sp. melonis, Fusarium oxysporum f.sp. radicis-lycopersici, Fusarium oxysporum f.sp. ciceris, Botrytis cinerea and Penicillium digitatum) showed that only two sponges (Haliclona viscosa and Cynachirella tarentina) are active against all phytopathogenic fungi studied.
\end{abstract}

Keywords: Antifungal activity; Porifera; Cynachirella; Marine sponges; Haliclona

\section{Introduction}

Agriculture in Morocco is an important economic sector, with $40 \%$ of the population living on its revenues. The agricultural area is estimated to be 9.5 million hectares. Fungi are the main responsible agents for losses in agriculture and horticulture and can infect any part of the plant (Messiaen et al. 1991). The fight against these fungi is based on the use of chemical pesticides. However, chemical pesticides sprayed into the air or discharged into the soil can be harmful to the environment and to humans as well.

More than 15000 natural products were isolated between 1965 and 2005 from marine organisms (Blunt et al. 2007). One of the main factors contributing to this trend is related to modern technology, and ocean biodiversity has become more accessible (Battershill et al. 2005).

Most marine invertebrates, which lack defence structures, have developed chemical defence systems in producing toxic secondary metabolites (Anderson et al. 1994; Aratake et al. 2009).

The sponges, which have a very primitive origin, adopted and developed a cemical very powerful defence (Sipkema et al. 2005) and are the source of many chemical compounds with various biological activities, including

\footnotetext{
* Correspondence: elamraouibelkassem@yahoo.fr

${ }^{1}$ Laboratoire Contrôle Qualité en Bio-Industrie et Molécules Bio-Actives, Faculté des Sciences, Université Chouaib Doukkali, BP 20, El Jadida 24000, Maroc

¿Université Ibn Zohr, Faculté Polidisciplinaire de Taroudant, Taroudant 82000, Maroc
}

antitumor (Acosta and Rodriguez 1992; Carmely et al. 1989), antiviral (Carter and Rinehart Jr 1978) antialgal (Wright et al. 2011), anti-inflammatory (Randazzo et al. 2001), antiparasitic (Galeano et al. 2011; Kossuga et al. 2008), antibacterial (Ankisetty and Slattery 2012; El Amraoui et al. 2014) and antifungal activities (Clark et al. 2001; El-Amraoui et al. 2013; Sata et al. 1999). These compounds also show the chemical diversity, and are composed among others of unusual nucleosides (Bergmann and Feeney 1951; Wang et al. 2009), peptides (Sjogren et al. 2006), and fatty acids (Carballeira et al. 2007; Carballeira and Pagan 2001; Pham et al. 1999).

Sponges consist not only of sponge tissue but also of microorganisms, which represent $50 \%$ of their mass. So, is that the antifungal that is secreted by the sponge or a microorganism associated with this sponge? The isolation of microorganisms associated to sponges and screening of antifungal metabolites produced by these microorganisms may provide an answer.

In Morocco, the researches of the metabolism products of medicinal plants and other groups of terrestrial or marine organisms are intensified to explore the possible use of metabolites in different areas. Despite the richness and biodiversity of the Moroccan sea, invertebrates and algae from seabed are poorly studied.

In this study, we report the antifungal activity of ethanol and dichloromethane extracts of ten marine sponges collected from Coastal Atlantic of El Jadida (Morocco) 
to select the most active species, which could be utilized to purify antifungal compounds.

\section{Results and discussion}

The identification of sponge species and their sampling sites are summarized in Table 1.

The results of the screening of antifungal activity of sponge extracts against phytopathogenic fungi are summarized in Table 2.

Among 20 extracts tested, only three extracts (15\%), showed antifungal activity against the studied phytopathogenic fungi.

Organic and hydroalcoholic extracts of $H$. viscosa exhibit antifungal activity whereas in C. tarentina, only the organic extract is active. This inhibition's effect can be shown in Figure 1.

The sponge genus Haliclona is known for its high chemical various secondary metabolites with interesting biological activities (Faulkner 2002) including the antifungal (Barrett et al. 1996; Clark et al. 2001; El-Wahidi et al. 2013), antileishmanial (Dube et al. 2007), antioxidant (Regoli et al. 2004), cytotoxic (Fusetani et al. 1989) and other activities (Lakshmi et al. 2009; Randazzo et al. 2001).

Up to now, the researches conducted on $H$. viscosa led to the isolation of a number of alkaloids. Fusetani et al. 1989 have isolated two cytotoxic compounds, haliclamine A and B from H. viscosa. Volk and Kock 2003 have isolated viscosamine, then viscosaline in Volk and Kock 2004. Recently, two forms of viscosaline have been isolated (Schmidt et al. 2012). In addition to this, two other alkaloids, haliclamine $\mathrm{C}$ and $\mathrm{D}$, were isolated from $H$. viscosa (Volk et al. 2004).

Lately, we have isolated a new product called haliscosamine from $H$. viscosa (El-Amraoui et al. 2013). This product is active against yeasts involved in human pathology. The chemistry of Cinachyrella tarentina sponge is rarely studied (El-Amraoui et al. 2010; El-Wahidi et al. 2011). This sponge was discovered in Italy (Pulitzer-Finali 1983),

Table 1 Sponge's identification and their sampling sites

\begin{tabular}{lll}
\hline Sampling sites & References & Sponges species \\
\hline Site $n^{\circ} 1$ & EM6 & Cliona celata \\
Site $n^{\circ} 2$ & EM8 & Cinachyrella tarentina \\
Site $n^{\circ} 3$ & EM7 & Ircinia oros \\
& EM11 & Ircinia spinulosa \\
& EM12 & Ircinia dendroides \\
& EM13 & Haliclona mediterranea \\
& EM14 & Haliclona viscosa \\
Site $n^{\circ} 4$ & EM5 & Axinella polypoides \\
Site $n^{\circ} 5$ & EM3 & Haliclona enamela \\
& EM10 & Cliona viridis \\
\hline
\end{tabular}

The geographical location and depth of sampling sites are shown in Figure 2.
Table 2 Antifungal activity of the marine sponge extracts

\begin{tabular}{lcccccc}
\hline Marine sponges & Extract & \multicolumn{5}{c}{ Inhibition diameter (mm) } \\
\cline { 2 - 7 } & & FOM & FORL & FOC & BC & PD \\
\hline Axinella polypoides & B & - & - & - & - & - \\
Haliclona enamela & C & - & - & - & - & - \\
Haliclona mediterranea & B & - & - & - & - & - \\
Haliclona viscosa & C & - & - & - & - & - \\
Cinachyrella tarentina & C & - & - & - & - & - \\
& B & - & - & - & - & - \\
& C & 20 & 16 & 19 & 21 & 20 \\
& B & - & - & - & - & - \\
C & C & 14 & 15 & 15 & 19 & 17
\end{tabular}

Cliona celata

Cliona viridis

Ircinia dendroides

Ircinia spinulosa

Ircinia oros

DESOGERME SP VEGETAUX ${ }^{\circledR}(100 \mu \mathrm{g}) \quad 28 \quad 26 \quad 28 \quad 29 \quad 34$

-: negative activity; FOM: Fusarium oxysporum f.sp. melonis; FORL: Fusarium oxysporum f.sp. radicis-lycopersici; FOC: Fusarium oxysporum f.sp. ciceris; BC: Botrytis cinerea; PD: Penicillium digitatum.

and now, we have collected this sponge from the Deauville beach, El Jadida, Morocco (El-Amraoui et al. 2010).

\section{Conclusion}

Preliminary results have shown that Moroccan sponges constitute a potential source of compounds, which can be used for crop protection. Haliclona viscosa and Cinchyrella tarentina have an interesting antifungal potential. Thus, these sponges provide a potential source of antifungal compound to fight against plant diseases and should be investigated for isolation of this natural compound.

\section{Materials and methods Phytopathogenic strains}

Strain of Fusarium oxysporum f.sp. melonis (FOM 20474 CECT) was obtained from Coleccion Espanola de Cultivos Tipo (Suárez-Estrella et al. 2007), Fusarium oxysporum f. sp. radicis-lycopersici (FORL), Fusarium oxysporum f.sp. ciceris $(F O C)$ and were obtained from the laboratory of Plant Pathology, Faculty of Sciences (El Jadida, Morocco), Botrytis cinerea (BC630) was obtained from biologybiochemistry department, Reims Champagne-Ardenne University, France and Penicillium digitatum (PD001), 


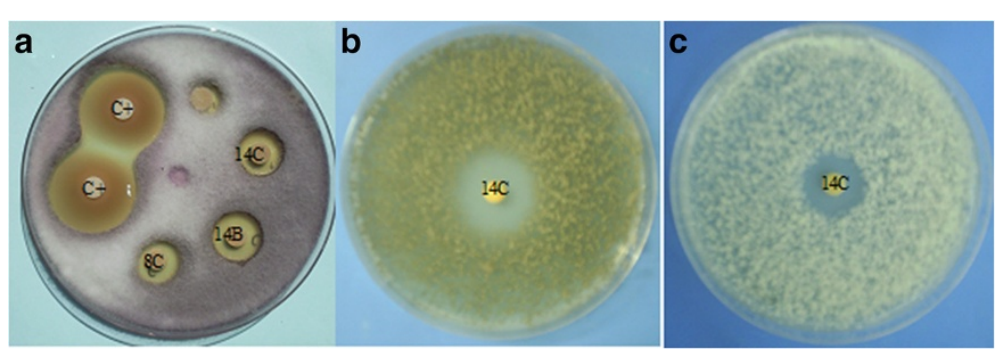

Figure 1 Example of antifungal activity of extracts of $H$. viscosa and C. tarentina against Fusarium oxysporum f.sp. melonis (a), Botritis cinerea (b) and Penicillium digitatum (c). (C+ : positive control (Desogerme sp); 8C: dichloromethane extract of C. tarentina; 14C: dichloromethane extract of $H$. viscosa; 14B: ethanol extract of $H$. viscosa).

isolated from an infected orange, were used throughout this study.

\section{Sponge materials}

Ten marine sponges were collected from five sites of the littoral Atlantic coast of El Jadida (Morocco). Figure 2 shows the locations and depths of sampling sponges. All the sponges were identified by Dr. Maria-Jesús Uriz, Research Professor at the Centro de Estudios Avanzados de Blanes (CEAB) and Consejo Superior de Investigaciones Cientificas (CSIC) Spain by morphological characteristics and molecular methods (El-Amraoui et al. 2010). The collected materials were immediately frozen at $-4^{\circ} \mathrm{C}$ for one night prior to extraction.

\section{Preparation of the extracts}

Each sponge (100 g wet weight) was thawed, and extracted with ethanol $(3 \times 100 \mathrm{ml})$. The ethanol was evaporated at reduced pressure. The suspension was completed with sterile water to $100 \mathrm{ml}$ and extracted with $\mathrm{CH}_{2} \mathrm{Cl}_{2}(3 \times 100 \mathrm{ml})$.
The $\mathrm{CH}_{2} \mathrm{Cl}_{2}$ extract was dried on anhydrous sodium sulphate $\left(\mathrm{Na}_{2} \mathrm{SO}_{4}\right)$, then filtered and concentrated at reduced pressure to give a $\mathbf{C}$ extract.

The aqueous phase was lyophilised and dissolved twice in absolute ethanol, then filtered and concentrated at reduced pressure to give a B extract (El-Amraoui et al. 2010).

\section{DESOGERME SP VEGETAUX ${ }^{\circledast}$}

DESOGERME SP VEGETAUX ${ }^{\bullet}$ (LAKORALE, Morocco), used in this study as a positive control, is an algaecide, fungicide and bactericide product used in Morocco both to remove algae, fungi and bacteria in irrigation systems and also to disinfect soil. It consists of $20 \mathrm{~g} / \mathrm{L}$ of polyhexamethyle bioguanidine hydrochlorique, and $50 \mathrm{~g} / \mathrm{L}$ of $\mathrm{N}$ alkyl dimethyl benzyl ammonium chloride.

\section{In vitro antifungal activity}

The antifungal activity was assessed in vitro by agar disc-diffusion test.

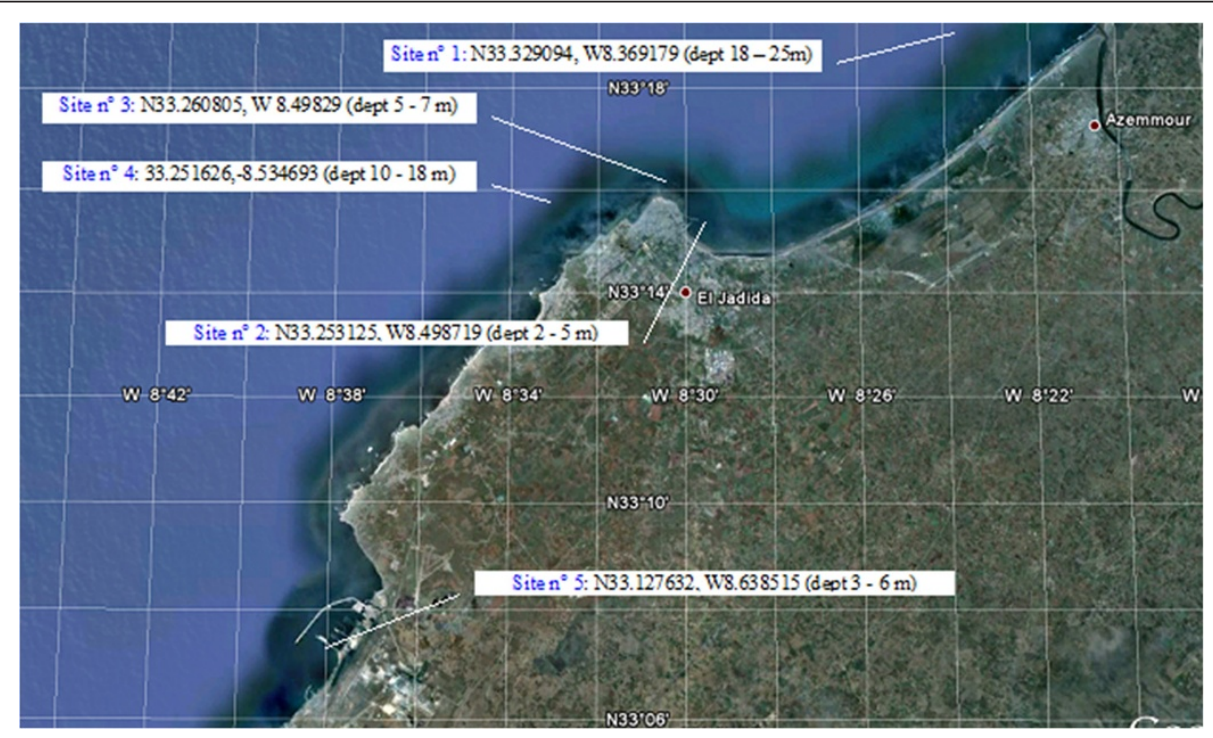

Figure 2 Map showing the locations and depths of harvesting sponges. 


\section{Agar disc-diffusion test}

This test uses Potato Dextrose Agar (PDA) as medium [Difco]. Conidial suspension was prepared from a 5-dold fungal culture and adjusted with Malassez's cellule in sterile water in order to obtain a final concentration of $10^{5} \mathrm{conidia} / \mathrm{mL}$. Each disk received $100 \mu \mathrm{g}$ of sponge extract $(20 \mu \mathrm{L}$ of each extract at $5 \mathrm{mg} / \mathrm{mL}$ were added to each cellulose disc) and was applied on the test media which were previously inoculated with each test strain (El-Amraoui et al. 2010). Plates were first kept at $4^{\circ} \mathrm{C}$ for at least two hours to allow the diffusion of chemicals, and then incubated at $28^{\circ} \mathrm{C}$. Inhibition zones were measured after $24 \mathrm{~h}$ of incubation (Galeano and Martınez 2007). Standard disks of DESOGERME SP VEGETAUX ${ }^{\circ}$ $(100 \mu \mathrm{g})$ served as positive antifungal control. All the assays were carried out in triplicate.

\section{Competing interests}

The authors declare that they have no competing interests.

\section{Authors' contributions}

All authors read and approved the final manuscript.

\section{Acknowledgements}

We thank Dr. Maria-Jesús Uriz, Research Professor at the Centro de Estudios Avanzados de Blanes (CEAB), Spain for sponge identification, F. Suárez-Estrella of Alméria University, Spain who provide us with a Fusarium oxysporum f.sp. melonis strains, Mr. Aziz Aziz Professor at the Reims Champagne-Ardenne University, France who provide us with a Botritis cinerea strains and M. Mouchene, director of the agricultural department in LACORALE society who provided us with a DESOGERME SP VEGETAUX`.

Received: 26 January 2014 Accepted: 20 October 2014

Published: 24 October 2014

\section{References}

Acosta AL, Rodriguez AD (1992) 11-oxoaerothionin: a cytotoxic antitumor bromotyrosine-derived alkaloid from the Caribbean marine sponge Aplysina lacunosa. J Nat Prod 55(7):1007-1012

Anderson AP, Beveridge AA, Capon R (1994) Pharmacological properties of the natural marine product furospongin-1. Clin Exp Pharmacol Physiol 21(12):945-953

Ankisetty S, Slattery M (2012) Antibacterial secondary metabolites from the cave sponge Xestospongia sp. Mar Drugs 10:1037-1043

Aratake S, Trianto A, Hanif N, de Voogd NJ, Tanaka J (2009) A new polyunsaturated brominated fatty acid from a Haliclona sponge. Mar Drugs 7(4):523-527

Barrett AG, Boys ML, Boehm TL (1996) Total synthesis of (+)-papuamine: an antifungal pentacyclic alkaloid from a marine sponge, Haliclona sp. J Org Chem 61(2):685-699, doi:jo951413z

Battershill C, Jaspars M, Lon P (2005) Marine biodiscovery: new drugs from the ocean depths. Biologist 52:107-114

Bergmann W, Feeney RJ (1951) Contributions to the study of marine products. The nucleosides of sponges. J Org Chem 16:981-987

Blunt JW, Copp BR, Hu WP, Munro MH, Northcote PT, Prinsep MR (2007) Marine natural products. Nat Prod Rep 24(1):31-86

Carballeira NM, Pagan M (2001) New methoxylated fatty acids from the Caribbean sponge Callyspongia fallax. J Nat Prod 64(5):620-623, doi:np000537q

Carballeira NM, Montano N, Vicente J, Rodriguez AD (2007) Novel cyclopropane fatty acids from the phospholipids of the Caribbean sponge Pseudospongosorites suberitoides. Lipids 42(6):519-524, doi:10.1007/s11745-007-3047-3

Carmely S, Roll M, Loya Y, Kashman Y (1989) The structure of eryloside A, a new antitumor and antifungal 4-methylated steroidal glycoside from the sponge Erylus lendenfeldi. J Nat Prod 52(1):167-170
Carter GT, Rinehart KL Jr (1978) Acarnidines, novel antiviral and antimicrobial compounds from the sponge Acarnus erithacus (de Laubenfels). J Am Chem Soc 100:4302-4304

Clark RJ, Garson MJ, Hooper JN (2001) Antifungal alkyl amino alcohols from the tropical marine sponge Haliclona n. sp. J Nat Prod 64(12):1568-1571, doi:np010246x

Dube A, Singh N, Saxena A, Lakshmi V (2007) Antileishmanial potential of a marine sponge, Haliclona exiqua (Kirkpatrick) against experimental visceral leishmaniasis. Parasitol Res 101(2):317-324

El Amraoui B, El Amraoui M, Cohen N, Fassouane A (2014) Antifungal and antibacterial activity of marine microorganisms. Ann Pharm Fr 72:107-111

El-Amraoui B, Biard JF, Uriz MJ, Rifai S, Fassouane A (2010) Antifungal and antibacterial activity of Porifera extracts from the Moroccan Atlantic coasts. J Mycol Med 20(1):70-74, http://dx.doi.org/10.1016/j.mycmed.2009.11.001

El-Amraoui B, Biard JF, Fassouane A (2013) Haliscosamine: a new antifungal sphingosine derivative from the Moroccan marine sponge Haliclona viscosa. Springerplus 2:252, doi:10.1186/2193- 1801-2-252 363

El-Wahidi M, El-Amraoui B, Biard JF, Uriz MJ, Fassouane A, Bamhaoud T (2011) Variation saisonnière et géographique de l'activité antifongique des extraits de deux éponges marines récoltées sur le littoral atlantique d'El Jadida, Maroc. Journal de Mycologie Médicale/Journal of Medical Mycology 21(1):28-32, http://dx.doi.org/10.1016/j.mycmed.2010.11.005

El-Wahidi M, El-Amraoui B, Fassouane A, Bamhaoud T (2013) Isolement bio-dirigé d'un antifongique à partir de Haliclona enamela récoltée du port de Jorf Lasfar, Maroc. Journal de Mycologie Médicale/J Med Mycol doi:10.1016/j. mycmed.2013.04.006

Faulkner DJ (2002) Marine natural products. Nat Prod Rep 19:1-48

Fusetani N, Yasumuro K, Matsunaga S, Hirota H (1989) Haliclamines A and B, cytotoxic macrocyclic alkaloids from a sponge of the genus Haliclona. Tetrahedron Lett 30:6891-6894

Galeano E, Martinez A (2007) Antimicrobial activity of marine sponges from Uraba Gulf, Colombian Caribbean region. J Mycol Med 17:21-24

Galeano E, Thomas OP, Robledo S, Munoz D, Martinez A (2011) Antiparasitic bromotyrosine derivatives from the marine sponge Verongula rigida. Mar Drugs 9(10):1902-1913, doi:10.3390/md9101902 marinedrugs-09-01902

Kossuga MH, Nascimento AM, Reimao JQ, Tempone AG, Taniwaki NN, Veloso K, Ferreira AG, Cavalcanti BC, Pessoa C, Moraes MO, Mayer AM, Hajdu E, Berlinck RG (2008) Antiparasitic, antineuroinflammatory, and cytotoxic polyketides from the marine sponge Plakortis angulospiculatus collected in Brazil. J Nat Prod 71(3):334-339, doi:10.1021/np0705256

Lakshmi V, Srivastava S, Kumar Mishra S, Misra S, Verma M, Misra-Bhattacharya S (2009) In vitro and in vivo antifilarial potential of marine sponge, Haliclona exigua (Kirkpatrick), against human lymphatic filarial parasite Brugia malayi: antifilarial activity of H. exigua. Parasitol Res 105(5):1295-1301

Messiaen CM, Blancard D, Rouxel F, Lafon R (1991) Les maladies des plantes maraîchères. INRA, Paris, p 552

Pham NB, Butler MS, Hooper JN, Moni RW, Quinn RJ (1999) Isolation of xestosterol esters of brominated acetylenic fatty acids from the marine sponge Xestospongia testudinaria. J Nat Prod 62(10):1439-1442, doi:np9901635

Pulitzer-Finali G (1983) A collection of Mediterranean Demospongiae (Porifera) with, in appendix, a list of the Demospongiae hitherto recorded from the Mediterranean sea. Annali del Museo Civico di Storia Naturale di Genova 84:445-621

Randazzo A, Bifulco G, Giannini C, Bucci M, Debitus C, Cirino G, Gomez-Paloma L (2001) Halipeptins A and B: two novel potent anti-inflammatory cyclic depsipeptides from the Vanuatu marine sponge Haliclona species. J Am Chem Soc 123(44):10870-10876

Regoli F, Nigro M, Chierici E, Cerrano C, Schiapparelli S, Totti C, Bavestrello G (2004) Variations of antioxidant efficiency and presence of endosymbiotic diatoms in the Antarctic porifera Haliclona dancoi. Mar Environ Res 58(2-5):637-640

Sata NU, Matsunaga S, Fusetani N, Van Soest RW (1999) Aurantosides D, E, and F: new antifungal tetramic acid glycosides from the marine sponge Siliquariaspongia japonica. J Nat Prod 62(7):969-971, doi:10.1021/np9900021 np9900021

Schmidt G, Timm C, Grube A, Volk CA, Kock M $(2012)$ Viscosalines B(1,2) and E $(1,2)$ : challenging new 3 -alkyl pyridinium alkaloids from the marine sponge Haliclona viscosa. Chemistry 18(26):8180-8189, doi:10.1002/chem.201101362

Sipkema D, Franssen MC, Osinga R, Tramper J, Wijffels RH (2005) Marine sponges as pharmacy. Mar Biotechnol (NY) 7:142-162 
Sjogren M, Johnson AL, Hedner E, Dahlstrom M, Goransson U, Shirani H, Bergman J, Jonsson PR, Bohlin L (2006) Antifouling activity of synthesized peptide analogs of the sponge metabolite barettin. Peptides 27(9):2058-2064, doi:S0196-9781(06)00159-8

Suárez-Estrella F, Vargas-Garcýa C, Lopeza MJ, Capelb C, Morenoa J (2007) Antagonistic activity of bacteria and fungi from horticultural compost against Fusarium oxysporum f.sp. melonis. Crop Prot 26:46-53

Volk CA, Kock M (2003) Viscosamine: the first naturally occurring trimeric 3-alkyl pyridinium alkaloid. Org Lett 5(20):3567-3569

Volk CA, Kock M (2004) Viscosaline: new 3-alkyl pyridinium alkaloid from the Arctic sponge Haliclona viscosa. Org Biomol Chem 2(13):1827-1830

Volk CA, Lippert H, Lichte E, Köck M (2004) Two New Haliclamines from the Arctic Sponge Haliclona viscosa. Eur J Org Chem 14:3154-3158

Wang B, Dong J, Zhou X, Lee K, Huang R, Zhang S, Liu Y (2009) Nucleosides from the marine sponge Haliclona sp. Z Naturforsch C 64(1-2):143-148

Wright AD, McCluskey A, Robertson MJ, MacGregor KA, Gordon CP, Guenther J (2011) Anti-malarial, anti-algal, anti-tubercular, anti-bacterial, antiphotosynthetic, and anti-fouling activity of diterpene and diterpene isonitriles from the tropical marine sponge Cymbastela hooperi. Org Biomol Chem 9:400-407

doi:10.1186/2193-1801-3-629

Cite this article as: El Amraoui et al:: In vitro screening of antifungal activity of marine sponge extracts against five phytopathogenic fungi. SpringerPlus 2014 3:629.

\section{Submit your manuscript to a SpringerOpen ${ }^{\circ}$ journal and benefit from:}

- Convenient online submission

- Rigorous peer review

- Immediate publication on acceptance

- Open access: articles freely available online

- High visibility within the field

- Retaining the copyright to your article

Submit your next manuscript at $\boldsymbol{\triangleright}$ springeropen.com 